\title{
PART 6. \\ THE UGCC AS A CHURCH-RELIGIOUS INSTITUTION OF INDEPENDENT UKRAINE
}

Adequate representation of the public place and state-building role of Greek Catholicism in independent Ukraine at the beginning of the third millennium is impossible without a thorough analysis of the profound transformational processes in the religious sphere of the state and particularly the western region in recent decades. It is known that until 1988 the official government of the UkrSSR-USSR implemented a policy of forced secularization of the population. In the 1988-1991 a religious favouritism of Russian Orthodox Church was a sign of religious policy of the government. However, in the western regions this process ended in 1989, followed by the shortlived favoritism of the Ukrainian Autocephalous Orthodox Church. The political defeat of the pro-communist forces in the 1990 local elections in the Lviv, Ivano-Frankivsk and Ternopil regions marked the beginning of a period of religious pluralization. On a nationwide scale, the religious pluralisation of society was proclaimed in 1991, the time when independence was proclaimed. However, the sharp turn of the state authorities from the traditional church-religious policy was caused not so much by the democratism of its statements as by the real threat of significant social unrest on the ethno-religious field.

An important component of the national liberation movement of the late 1980s - early 1990s became a wide public movement for the restoration of the Ukrainian Greek Catholic Church, which "in its scope went beyond purely religious issues and acquired a political character" $^{\prime \prime 68}$.

The UGCC has shown exceptional vitality, and its clergy and believers - an unwavering faith in the restoration of the parental Church. The foundation of the Church's revival was the existence of

468 Кобута С. Політичні аспекти легалізації Української Греко-Католицької Церкви (1987-1991). Людина і політика. 1999. № 3. С. 23. 
active underground organization. According to the head of the UGCC in Rome, Cardinal Myroslav Lubachivsky, in the late 1980's, its underground consisted of ten bishops, about one thousand priests, one thousand two hundred monks and nuns, and 4.5 million believers ${ }^{469}$.Other data include reports from official authorities: in 1988 in the Lviv, Ternopil, Ivano-Frankivsk and Transcarpathian regions there were 260 priests, 385 monks and nuns and only 100,000 Greek Catholics believers ${ }^{470}$.

Movement for the legalization of the UGCC has been especially strengthened since the start of Mikhail Gorbachev's reforms, who in 1985 , in the face of a clear socio-economic crisis of the Soviet totalitarian system began a radical change in politics for its preservation. A course on the democratization of society, publicity and pluralism was proclaimed.

The turning point was the meeting of $\mathrm{M}$. Gorbachev with the hierarchs of the ROC on April 29, 1988 at which the General Secretary declared abolition of discriminatory acts on religion, return of the usurped churches to the communities, preparation of the new state law on freedom of conscience. He stressed that restructuring, publicity and democracy, without any restriction, refer to state-church relations ${ }^{471}$. This decision, among other reasons, was prompted by the state-level celebration of the 1000th anniversary of the baptism of Rus'-Ukraine. By the way, on this occasion Pope John Paul II in July 1988 in the St. Peter's Cathedral celebrated a Liturgy in Ukrainian language for 15,000 Greek Catholics of the West ${ }^{472}$

In order to avoid an aggravation of the religious situation the leaders of the UGCC in Rome have made attempts to contact and communicate with the leaders of the ROC in the USSR. In particular, on November 6, 1987 Cardinal M. Lubachivsky made an appeal to the Orthodox hierarchs with a proposal for reconciliation. The Synod

\footnotetext{
469 Кобута С. Політичні аспекти легалізації Української Греко-Католицької Церкви (1987-1991). Людина і політика. 1999. № 3. С. 24.

${ }^{470}$ ЦДАГО України. Ф. 1. Оп. 25. Спр. 3143. Арк. 41; Спр. 3330. Арк. 9-20; арк. 27.

471 Правда. 1988. 30 апреля.

472 Слово Святішого Отця Івана Павла II до України. Львів, 2001. С. 86-92.
} 
of Bishops of the UGCC, held in the Vatican from September 24 to October 8, 1988, made a similar appeal ${ }^{473}$.

However, in August 1987 a group of Lviv priests left the underground and signed a collective statement to Moscow for the legalization of the UGCC. This movement, which was widely supported by Greek Catholics, was led by Bishop from IvanoFrankivsk Pavlo Vasylyk ${ }^{474}$. Also in 1987, referring to the declared in Constitution of the USSR freedom of conscience, two bishops and 23 priests issued a petition-appeal to Pope John Paul II about leaving the underground and requests to support "in every possible way the case of legalization of Ukrainian Catholic Church in the USSR" "475. In October 1988, a delegation of the Ivano-Frankivsk eparchy of the underground UGCC arrived in Moscow and negotiated with the Council for Religious Affairs at the Council of Ministers of the USSR on the legalization of the Church. However, they ended without success, as the authorities at the time considered such statements and facts of the exit of parishes from the underground as a kind of manifestations of religious extremism. Moreover, on the orders of Moscow, the party organs of Ukraine tried to neutralize the activity of believers of the underground Church.The media intensified propaganda campaign to discredit the UGCC and anti-union content was urgently printed ${ }^{476}$.

The socio-religious movement in Western Ukraine was flowing into the powerful stream of the Ukrainian national revival of the late 1980s. The desire of the Soviet authorities for a democratic image in the world community narrowed its capabilities to combat it. In 1987, Moscow was forced to release about 300 Ukrainian political prisoners out of the 350 who, through formal publicity, were strongly involved in further fighting the totalitarian system. Leaders of the Ukrainian Helsinki Group, the Initiative Committee for the Release of Prisoners

\footnotetext{
473 Поступ. 2000. 13 травня.

474 Бюлетень релігійної інформації. 1997. № 13-14; Ієрархи Української Греко-Католицької Церкви в Україні. Поступ. 1999. 11 вересня.

${ }^{475}$ ЦДАГО України. Ф. 1. Оп. 25. Спр. 330. Арк. 9-20.

476 Ржезац Т., Цуркан В. Розшукуються... Київ, 1989. С. 20-113; Пащенко В. Греко-католики в Україні (від 40-х років XX століття до наших днів). Полтава, 2002. C. 446.
} 
of Conscience L. Lukyanenko, V. Chornovil, I. Gel, M. Horyn, S. Khmara actively supported the legalization of the UGCC. At the end of 1987 a recent political prisoner, Ivan Gel, founded the Committee for the Protection of the UGCC, which included church leaders. In order to promote social and political movement for the revival of the Church he established edition of the magazine "Christian voice" $"$.

The catalysts for the legalization of the underground Church were also the obstacles created by the authorities in celebration of the millennial anniversary of Baptism in 1988. Actually, at that time, Greek Catholics were able to conduct unauthorized by the authorities mass worships in the village Hrushiv of Lviv region and the village Zarvanytsya of Ternopil region. This once again drew the attention of the anti-communist opposition and the public to the problem of respect for the rights of believers and freedom of religion in the USSR. Thus, a wave of new church services of political character swept through many settlements in Lviv, Ivano-Frankivsk and Ternopil regions.

Groups of Greek Catholic bishops and priests have repeatedly appealed to higher authorities and international organizations for the legalization of the Church. In January 1989, Ivano-Frankivsk Bishop P. Vasylyk one more time requested M. Gorbachev to meet and negotiate on "urgent issues related to the organization of the Church"478. In May of the same year, a delegation of bishops and priests of the UGCC arrived to Moscow with a petition for M. Gorbachev to restore the Church, and they also negotiated in the Council on Religious Affairs. When the delegation did not receive a positive response, a group of Greek Catholics began a hunger strike in Moscow, which lasted until the end of November, 1989. In addition, petitions were sent to states-participants of the Vienna and Paris forums of the Conference on Security and Cooperation in Europe. Special attention was paid to the events in honor of the 1000th anniversary of the baptism of Rus'-Ukraine. When President Gorbachev met with Pope John Paul II in Rome and established

\footnotetext{
${ }^{477}$ ЦДАГО України. Ф. 1. Оп. 25. Спр. 3143. Арк. 49.

478 Документи патріаршого Собору Української Греко-Католицької Церкви. Перша сесія. Жовтень 1996 рік. Львів: Свічадо, 1998. С. 26.
} 
diplomatic relations between the USSR and the Vatican, it became possible to raise the issue of legalization of the UGCC and the registration of its communities at the highest level. As a result of these measures the Kremlin agreed to prepare a new law on freedom of conscience, which would be consistent with international legal acts on issues of human rights and religious freedom ${ }^{479}$.

Revival of the UGCC was actively promoted by Ukrainian sociopolitical groups: People's Movement of Ukraine, Helsinki Union, Ukrainian Christian Democratic Front, etc. The first gathering of the Movement in September 1989, which brought together about 280,000 members, adopted a resolution "On Churches in Ukraine". It declared freedom of religion, filled with real meaning the law on separation of the Church from the state, accused the ROC of serving the Communist regime, demanded legalization of the UGCC and condemned the Moscow Patriarchate for obstacles to the revival of national churches ${ }^{480}$. Nevertheless, the second gathering of the Movement in 1990, when the problem of legalization was solved and the process of revival and reconstruction of the Ukrainian Greek Catholic and Autocephalous Orthodox Churches began, noted the important role of religious factors in state building ${ }^{481}$.

Recognizing dangerous for the system situation in Ukraine, particularly in the western regions, party and security forces prevented the Greek Catholic movement from growing. They had high expectations of the Orthodox Church, whose hierarchy was openly opposed to the legalization of the $\mathrm{UGCC}^{482}$. Therefore, the Communist Party, the authorities and the ROC were united against the revival of the UGCC. Undoubtedly, the leaders of the ROC did not want to lose their influence in the western region, because in 1986 there were 1852 out of 6747 (27\%) ROC religious communities concentrated - one half of 4,418 (in 1988) Orthodox parishes in Ukraine. Their return to the UGCC could have seriously damaged the prestige and financial positions of Russian Orthodoxy. Thus, the state-level anti-unitary campaign, strengthened by the hierarchs of the

\footnotetext{
${ }^{479}$ Історія релігії в Україні. Київ: Знання, 1999. С. 614.

480 Літературна Україна. 1989. 19 жовтня; Вістник Руху. 1990. № 5. С. 20.

481 Літературна Україна. 1990. 1 листопада.

482 Правда Украины. 1989. 23 мая.
} 
ROC, continued until the end of 1989. During this period, the agonizing state transferred about 800 inactive temples to the ROC in Galicia, in order to avoid claims by Greek Catholics in the future. However, there was no unity among the Orthodox hierarchy ${ }^{483}$

In the second half of 1989 mass protests by Greek Catholics coordinated by hierarchs led by Archbishop Volodymyr Sterniuk gathered crowded religious actions. Its apogee - the demonstration of 100,000 people on September 17, in Lviv, under the slogans of legalization of the UGCC. The process of self-revitalization of the Greek Catholic faith developed into the possessing of parent churches. The first in the region to become the property of the UGCC on October 29 was the Transfiguration Cathedral in Lviv and the Church of the Holy Trinity in Shchyrka in Lviv region. Realizing that the process of reviving the Church could not be stopped, party-state officials tried to put it under their control. On November 21, 1989 the Council in Religious Affairs of the Council of Ministers of the UkrSSR issued a statement authorizing the registration of Greek Catholic communities, which were granted all the rights established by law for religious associations ${ }^{484}$.

Archbishop V. Sterniuk gathered the ecclesiastical council of the UGCC in Lviv on January 23, 1990 with the participation of six bishops and 150 priests. It proclaimed the legalization of the Church, recognized the pseudo-council of 1946 in Lviv as non-canonical, made demands to rehabilitate repressed representatives of the Greek Catholic clergy, to return to the Church its temples and to recognize the church organization of the UGCC. This act led to the process of mass transfer of the believers from Orthodoxy and registration of the Greek-Catholic communities. In February 1990, more than 435 applications for registration of the restored parishes were done. In addition, by the end of the year, 1677 Greek Catholic communities had been revived ${ }^{485}$. In early 1989, Bishop Sofron Dmyterko (who

\footnotetext{
${ }^{483}$ Московский церковный вестник. 1989. № 17. С. 3.

484 Ibid. Арк. 41.

485 Васьковський В. «Горячі точки»: стан справ і шляхи врегулювання. Людина i cвim. 1990. № 10. C. 31 .
} 
ordained more than 65 priests during the underground period) legalized pastoral activity in Ivano-Frankivsk ${ }^{486}$.

The decisive role in the process of community legalization was played by the initiative of democratically elected local councils, which, despite the uncertain policy of Kyiv, adopted radical statements and easily implemented them. In particular, on May 4, 1990, the Lviv Regional Council adopted a resolution "About religious denominations in Lviv region", which defined the procedure for the transfer of temples to the restored denominations, the St. George's Cathedral - the historical residence of the Metropolitan of the UGCC - returned to the Metropolitanate. Lviv Regional Council proposed to the Verkhovna Rada of UkrSSR to consider restoring the rights of the Ukrainian national churches ${ }^{487}$.

At the time of the UGCC's exit from the underground and during the first recovery period, it had only three eparchies in Ukraine: Lviv, Ivano-Frankivsk, and Mukachevo, which through the Apostolic Nuncio in Ukraine was subordinated to the Vatican. They formed the Metropolitanate of Lviv, led by Archbishop Volodymyr Sterniuk, the head of the UGCC - High Archbishop and Cardinal Myroslav-Ivan Liubachivsky was in Rome. On February 3-10, 1991, the last out-ofUkraine Synod of the entire hierarchy of the Church, with the participation of bishops from Western Ukraine, gathered in the Vatican. They discussed the situation in Ukraine and decided to move the Head of the UGCC to Lviv ${ }^{488}$. Already on March 30, Metropolitan M. Liubachivsky arrived at the historical centre of the UGCC in Ukraine and celebrated the Bishops' Mass in the St. George's Cathedral and on the next day he attended a grand academy where he was greeted by the leaders of the region and thousands of Greek Catholics $^{489}$.

\footnotetext{
486 «Вірю, що усі з’єднаємося у Христі»: Інтерв’ю 3 Ординарієм ІваноФранківським Владикою Софроном Дмитерком ЧСВВ 3 нагоди його 80-літнього ювілею. Нова зоря. 1997. 27 травня.

${ }^{487}$ Постанова Львівської обласної ради. Людина і світ. 1990. № 9. С. 13.

${ }^{488}$ С тоцький Я. Історичні аспекти відновлення, реорганізації та структурування православних і католицьких церков в Україні у 1988-1999 роках. Київська Церква. Київ; Львів, 1999. № 2-3. С. 54.

489 За вільну Україну. 1991. Червень. Спецвипуск.
} 
The arrival of the Head of the UGCC in Ukraine and his approval on the St. George's throne marked the final legalization of the Church, the end of the catacomb existence and the beginning of a new era in its history. The long-standing struggle of the Ukrainian people for the revival of the national Church ended with victory.

On April 23 of that year, the Verkhovna Rada of the UkrSSR adopted the Law "On Freedom of Conscience and Religious Organizations", which regulated one of the most important problems of the ethnic and national development of society. Finally, all bans on religion and ecclesiastical organizations were lifted and citizens of the republic were legally granted the right to freedom of conscience and religion, the interests of believers and religious organizations were combined with the interests of the state ${ }^{490}$.

Thus, religion acquired a new social status, filled with ethnonational content. This was a period of radical rethinking of the role and place of religion in society and the state, the return to the people's life of the rites, customs and historical traditions of national spirituality. Some legislative acts in Ukraine recognized such religious holidays as Christmas, Easter, Trinity.

On July 16, 1990, in a deep crisis of the totalitarian regime and the collapse of the USSR, after a fierce struggle between the democratic and communist parliamentary blocs, the Verkhovna Rada of the UkrSSR adopted the Declaration of State Sovereignty of Ukraine ${ }^{491}$, which proclaimed "the rule, autonomy, completeness and indivisibility of the power of the republic within its territory, and independence and equality in external relations!". The attempt of the Kremlin military-party bureaucracy through a coup d'etat on August 19-21, 1991 to save the communist empire ended in failure and accelerated the final collapse of the USSR. On August 24, an extraordinary session of the Verkhovna Rada adopted the Resolution and the Declaration of Independence of Ukraine. Ukraine has become an independent democratic state with an indivisible and inviolable

\footnotetext{
490 Закон України «Про свободу совісті та релігійні організації». Відомості Ради УРСР. 1991. № 25. С. 656-666.

491 Зайцев О., Зайцев Ю. На шляху до незалежності. Історія України. Вид. 2-ге. Львів: Світ, 1998. С. 407.
} 
territory with only its own constitution, laws and regulations of the government $^{492}$.

With the proclamation of independence, UGCC believers, along with the believers from other denominations, were given the opportunity to perform their rights, both religious and national-state. However, in the sphere of ecclesiastical relations Ukraine received the complex inter-denominational relations from the communist regime. There were many obstacles to the religious revival in general, and the restoration and reconstruction of the UGCC in particular. In those days, there were three major, most numerous Christian churches in Ukraine: the Ukrainian Orthodox Church, headed by Metropolitan Filaret (5 031 religious communities), subordinated to the Moscow Patriarchate as an autonomy, Ukrainian Greek Catholic (1912 Communities) led by Patriarch and High Archbishop Cardinal Ivan Myroslav Liubachivsky and Ukrainian Autocephalous Orthodox Church led by Metropolitan Mstyslav (811 communities) ${ }^{493}$. The appearance in the arena of the religious life of the Ukrainian national churches of the UGCC and the UAOC significantly narrowed the influence of the Russian Orthodox Church, that is, its exarchate of the UOC. The Ukrainianization of the religious and ecclesiastical sphere did not suit Moscow at all, and the hierarchy of the Russian Orthodox Church strongly committed obstacles in the development of national churches. In addition, there were no friendly relations between the hierarchs of the UGCC and UAOC who tried to establish themselves in Western Ukraine and struggled for influence. However, inside the complex inter-denominational processes, sometimes through sharp inter-denominational conflicts, the UGCC has demonstrated a truly record-breaking tempo of its revival and development. It should be noted that the revival of ethno-national and religious life in the western region of Ukraine took place in the conditions of taking of power structures by national patriotic forces. In particular, in the Lviv, Ternopil, Ivano-Frankivsk regions the executive bodies were headed by the representatives of the Movement. In the elections to the Verkhovna Rada of Ukraine, the democratic bloc won in five oblasts: Lviv (all 24 Movement candidates), Ivano-Frankivsk, Ternopil,

492 Ibid. C. 433.

493 Людина і світ. 1991. № 5. С. 41. 
Volyn, and Kyiv ${ }^{494}$, which were forced to pursue their policies in the religious sphere on the principles of religious pluralism.

The persecution of the Ukrainian Greek Catholic Church by Communist Party, liquidation of its organizational structures as well as educational institutions, long-standing information blockade and other repressive measures by the Soviet authorities, imperial activities of the Moscow ROC, caused a number of problems, that were facing hierarchs and clergy to revive the national church. The most important among these were the general aspects of national-spiritual revival, raising the role of religion in the spiritual life of society, establishing the place of lay people in the process of state-building, the consolidation of ethnic groups in independent Ukraine.

First of all, it was necessary to restore and improve the organizational structure. In general, the UGCC came out of the underground being structured. It had an extensive network of parishes, underground seminaries, which filled the priesthood ranks, the centers of monastic life, and, most importantly, a big amount of faithful lay people. At the time of the legalization of the UGCC, there were three eparchies: Lviv, Ivano-Frankivsk and Mukachevo, which was directly under the control of the Vatican. The of Lviv and IvanoFrankivsk eparchies constituted the Metropolitanate of Lviv, which was headed by Archbishop Volodymyr Sterniuk before the arrival from Rome the Head of UGCC ${ }^{495}$.

With the active participation of the Lviv, Ivano-Frankivsk and Ternopil communities, Greek Catholic structures were being built in the east of the country, including the capital. In 1991, the Kyiv State Administration passed to Greek Catholics the Church of St. Nicholas on the Askold's Grave. Among the founders of the community were artist Nina Boyko, professor of architecture Larysa Skoryk and other well-known scientists, politicians and artists. According to the first parish priest, Ihor Onyshkevych (Order of St. Basil the Great), this church "should become a temple of prayer for all who gave their lives

\footnotetext{
494 Зайцев О., Зайцев Ю. На шляху до незалежності. Історія України. Вид. 2-ге. Львів: Світ, 1998. С. 406.

${ }^{495}$ Стоцький Я. Історичні аспекти відновлення, реорганізації та структурування православних і католицьких церков в Україні у 1988-1999 роках. Київська Церква. 1999. № 2-3. С. 54.
} 
for the freedom of Ukraine, sacrificed themselves for the Church of Christ" and therefore "has become the throne of Christian martyrs" After his arrival in Ukraine, the High Archbishop Cardinal Myroslav Ivan Lubachivsky in May 1992 called the first after 1946 Synod of Bishops on the Ukrainian soil. 28 bishops from Ukraine and the diaspora came to Lviv to discuss the urgent problems of building the Church. As a significant achievement there was marked the increase of number of Greek Catholic communities up to 2700 , restoration of the 33 monasteries and 5 religious schools ${ }^{497}$.

One of the painful problems in the process of building the Church was the lack of high-level priests training. Indeed, according to 1996 statistics, the situation with the clergy, their experience and education was difficult. In particular, in the Sambir-Drohobych diocese of 184 priests 108 were from the spiritual institutions of independent Ukraine, 65 were transferred from the Russian Orthodox Church, and only 11 parishioners who left the underground, were educated and ordained before 1946, or trained in underground seminaries ${ }^{498}$. The situation in the Ternopil Eparchy was even more complicated at this time, where out of 226 priests, 160 , or $70 \%$, were young people who came from the revived seminaries. 53 parishioners passed from Orthodoxy and 13 came from the underground ${ }^{499}$. The diversity of priesthood training, the heterogeneity of their education and work experience have adversely affected the overall condition of the Church.

It should be noted that the Consistory of the Metropolitanate together with the hierarchs of the Church in Ukraine and the diaspora, tried to improve the situation in this area. In 1994, the Theological Academy was restored in Lviv and enrolled 127 of its first students. Five institutes operate at the academy ${ }^{500}$. Among them is the Institute for the History of the Church, the first non-governmental scientific institution to investigate the situation of the Church under the

\footnotetext{
496 Онишкевич Ігор Ілля «Ми молемося за єдність українських християн...». Нова зоря. 1993. Вересень. Ч. 35-36.

497 Людина і світ. 1992. № 11-12. С. 43.

${ }^{498}$ Ibid. 1992. № 11-12. C. 11.

${ }^{499}$ Ibid. C. 15.

${ }^{500}$ Ibid. 1998. № 10. C. 27.
} 
conditions of a totalitarian communist regime. Its activity is based on the method of "living history", which means the collection of oral testimony and their computer analysis. The Institute publishes a digest of church history "The Ark" (Part 1, 1993; Part 2, 2000) organized a series of "Brest readings", prepares collections of documents $^{501}$. There is also a Training Institute at the academy where priests deepen religious knowledge.

In 1994, the Institute of Higher Religious Culture at the University of Lublin (Poland) was opened for Greek Catholics, where in 1996 250 students - priests, monks and nuns - studied, 45 of them completed a two-year course and received diplomas ${ }^{502}$. All these measures have undoubtedly changed for the better the staffing situation in the short time of the Church's reconstruction process. A total of 1678 future priests were educated in eight educational institutions of the UGCC in $1994^{503}$. Improvement of this sphere continues. Within the Church there is also a hospital named after Metropolitan Andrey Sheptytsky, radio "Voskresinnya", the TV channel "Sobor" TV, the publishing houses "Missionary", "Svichado", "Nova Zorya" and others.

The celebration of the 400th anniversary of the Union of Brest was a powerful impulse for raising the authority of the UGCC and its further development. Major anniversary events took place in Rome, led by Pope John Paul II, with the participation of all Greek Catholic hierarchs and cardinals, archbishops, bishops of the Latin Church. At the opening of the Synod of Bishops of the UGCC in the Apostolic Capital on 16 November 1995, the Apostolic Letter of the Pope on this historic date was published ${ }^{504}$. In a speech at the Synod of Bishops of the UGCC, referring to the Ukrainian hierarchy, the Pope called: "Worthy Brothers! The upgrade process - and you know it well - will be long and will require patience and resilience, but it will

\footnotetext{
${ }^{501}$ Інститут історії Церкви Львівської богословської академії. Львів, 2000. 20 с.

502 Документи патріаршого Собору Української Греко-Католицької Церкви. Перша сесія. Жовтень 1996 рік. Львів: Свічадо, 1998. С. 5.

${ }^{503}$ Головащенко С. Історія християнства. Київ: Либідь, 1999. С. 300.

${ }^{504}$ Католицький щорічник 1996. Київ, 1996. С. 8-10; Місіонар. 1996. № 13. С. 8-9.
} 
surely bring the expected results.You are on the right way. Continue to finish what you started" $" 505$.

The main celebrations of the Brest Jubilee in Ukraine took place in October 1996. At the altar in the square, near the Opera House in Lviv, Cardinal Myroslav Ivan Lubachivsky celebrated the Holy Liturgy. A solemn academy was held at the high-level in Opera House, announcing congratulations from the Government of Ukraine and honorable guests. They expressed recognition of the historical merits of the Greek Catholic Church for the Ukrainian people and the national-patriotic, state orientation of its activities during the period of struggling for independence of Ukraine, the revival and development of the Church $^{506}$.

At the same time, in October 1996, Metropolitan Cardinal M. Lubachivsky called the Council of the UGCC. It was attended by all hierarchs of Ukraine and diaspora who reported on the activities of eparchies and exarchates. Initially, the main slogan of the Council was: "Moral and Spiritual Revival of Ukraine and Ecumenism"507. On behalf of the Government of Ukraine, the Council was first congratulated by the Chairman of the State Committee for Religious Affairs of Ukraine A. Koval ${ }^{508}$.

The Patriarchal Council of the UGCC in 1996 also noted the progress in the revival and development of the monastic orders, whose activity in Ukraine was traditional until the ruins of the 1940s. The most numerous and influential was the Order of St. Basil the Great, which up to 1939 consisted of three provinces (Galician, Transcarpathian, and overseas American-Canadian), had 49 monasteries and 650 monks. On the lands of Ukraine the communist regime closed and appropriated all monasteries (31), most of the 350 monks were repressed ${ }^{509}$. Following the legalization of the UGCC, 17 monasteries have been returned to the Basilians in

\footnotetext{
${ }^{505}$ Ibid. C. 30.

506 Сапеляк А. Київська Церква на слов'янському Сході. Буенос-Айрес; Львів, 1999. С. 212-213.

507 Документи патріаршого Собору Української Греко-Католицької Церкви. Перша сесія. Жовтень 1996 рік. Львів: Свічадо, 1998. С. ХІ-ХІІ.

508 Ibid. C. XXI.

509 Людина $і$ світ. 1998. № 10. С. 27; Львівська богословська академія. Львів, 2000. $90 \mathrm{c}$.
} 
Ukraine, which fully resumed their pastoral work, and are serving 62 parishes and about 250 affiliated churches and missions in 9 villages in eastern Ukraine ${ }^{510}$. The great importance for the Church had the renewed Basilian publishing office established by Metropolitan Andrey Sheptytsky in 1898. Thanks to the Western Diaspora, the Basilian printing house in Zhovkva was modernized and in a short time published hundreds of books of religious content $^{511}$. Therefore, for a short period, as early as the mid-1990s, the Greek Catholic Church solved the problem of structuring and come to the Christian world with a grand structure with a large-scale religious life and a well-developed national-state ideology. It, having a great influence on the laity of the western region of Ukraine, conquered supporters in the east and gained an important place in society.

\footnotetext{
${ }^{510}$ Інститут історії церкви Львівської богословської академії. Львів, 2000. 20 с.

511 Документи патріаршого Собору Української Греко-Католицької Церкви. Перша сесія. Жовтень 1996 рік. Львів: Свічадо, 1998. С. 29.
} 